\title{
BIOREMEDIATION OF SOME AGRICULTURAL WASTES BY BACILLUS THURINGIENSIS FOR METALLOPROTEASE PRODUCTION
}

\author{
Nashwa M. H. Rizk; Ayman S. Eldourghamy* and Eman G. Elgamal \\ Environmental Biotechnology Department. Genetic Engineering and Biotechnology \\ Research Institute. University of Sadat City. Egypt \\ Corresponding author: e-mail: eldorghamy@yahoo.com
}

\begin{abstract}
Agricultural wastes are very rich in nutrients that can be used as complete balanced microbiological media for growing microbes in order to produce valuable commercial products. In this study, a biodegradation process of wheat bran and rice bran wastes was carried out to produce metalloprotease enzyme from B. thuringiensis 1257strain which is considered to be a hyper producer for that enzyme. Metalloprotease was partially purified by ammonium sulfate followed by application on Sephadex G-75 column. Gel filtration step resulted in more than 40 times fold purification of the purified enzyme. The enzyme activity was inhibited by EDTA (almost $80 \%$ ) at $15 \mathrm{mM}$ concentration. These agro-industrial wastes were used as substrates for economic production of the enzyme from $B$. thuringiensis compared with some bacterial isolates collected from different sites in Kafr El-Sheikh and Menofiya governorate, Egypt. Optimum temperature for enzyme activity was $40{ }^{\circ} \mathrm{C}$. It also exhibited a broad $\mathrm{pH}$ activity range (6-9) with an optimum $\mathrm{pH}$ of 8 .
\end{abstract}

Key words: metalloprotease, B. thuringiensis1257,EDTA,agro-industrial waste, Sephadex G-75

\section{INTRODUCTION}

Agricultural wastes all over the world are produced in a huge amount annually (about 140 billion metric tons). Most applicable researches were carried out to use this massive amount of nutrients-rich wastes for production of commercially valuable biomolecules . Protein and enzymes are examples of these biomolecules which are produced via solid state fermentation processes of agro industrial wastes. Metalloproteases were produced by biodegradation of protein-rich agricultural wastes supplemented with nitrogen sources (Saxena and Singh, 2010).

Recently, pharmaceutical and biocatalyst enzymes production via different biodegradation processes reached 6.3 percent per year of the world enzyme demand. Industrial and medical enzyme industries are also expected to expand in developing countries where there are several governmental attentions towards the expansion in the industrial sector. With pharmaceutical companies having

difficulty bringing new smallmolecule drugs to market, biotechnology will be the cheap and clean solution, helping to sustain demand for research and biotechnology enzymes. The world Sin 2013. The most demanded industrial enzymes are nucleases, polymerases, lipases, amylases and proteases.

Metallo-proteases (metallo, metal) are members of proteases that contain a metal ion at their active site. These enzymes act as catalysts in the hydrolysis of peptide bonds (Hooper, 1994).Zinc metalloprotease is one of the most common members of this class of enzymes, it contains a zinc ion $(\mathrm{Zn} 2+)$ in its active site (Claudia and Richard, 1993). Other transition metals have been found at the active sites of different metallo-proteases such as $\mathrm{Co}^{2+}$ and $\mathrm{Mn}^{2+}$.It was found that $\mathrm{Co}^{2+}$ and $\mathrm{Mn}^{2+}$ could be used to restore function in zincmetalloproteases in which the $\mathrm{Zn}^{2+}$ core has 
been removed (Holmquist and Vallee, 1990). Generally, metal ions are bound in a nearly tetrahedral conformation at the active site. The metal core is mainly consisted of three amino acid ligands, together with one water molecule which is used for hydrolysis (Vallee and Auld, 1990). There are two major subclasses of metalloproteases: metallo-endo peptidases and metalloexo-peptidases. Each subclass is named according to the region of hydrolysis in targeted protein at which the reaction takes place.

Because metallo-proteases play key roles in many normal biological processes, their abnormal activities have been implicated in many diseases such as arthritis, cancer, cardiovascular diseases, nephritis, disorders in the central nervous system, fibrosis, and infection (Nagase, 2001).

Early studies regarding metalloproteases has shown that the degradation of extracellular matrix components represents the first function performed by these enzymes and has focused the attention on their fundamental roles in immunity. Other important functions of metalloproteasesare immune cell development, effector function, migration and ligandreceptor interactions. They carry out ectodomain shedding of cytokines and their cognate receptors. Together with their endogenous inhibitors TIMPs (tissue inhibitor of metalloproteinases), these enzymes regulate signaling downstream of the tumor necrosis factor receptor and the interleukin-6 receptor, as well as that downstream of the epidermal growth factor receptor and notch, which are all pertinent for inflammatory responses (Khokha et al. 2013).

Metallo-proteases have also a role in the pathological destruction in diseases such as rheumatoid arthritis and osteoarthritis, and the irreversible nature of the ensuing cartilage and bone damage. This important role has led to the development of metallo-protease inhibitors as potential therapeutics. Recently it has been reported that several zinc dependent proteases have significant roles in the biology of the resident cells in these tissues. They also play key roles in the activity of inflammatory cells (Murphy and Lee, 2005). These enzymes play key roles in the responses of cells to their microenvironment. By effecting proteolytic degradation or activation of cell surface and extracellular matrix $(\mathrm{ECM})$ proteins which influence cell differentiation, migration, proliferation and survival (Baker et al. 2002).

On industrial scale, microorganisms are the most important sources for metalloproteases production. Selection of the right organism plays a key role in high yield of desirable enzymes. For production of enzymes for industrial use, isolation and characterization of new promising strains using cheap carbon and nitrogen source is a continuous process. Habitats that contain protein are the best sources to isolate the proteolytic microorganism. Waste products of meat, poultry and fish processing industries can supply a large amount of protein rich material for bioconversion to recoverable products (Gaustevora, et al. 2005). Many of the organisms produce more than one kind of protease. The type of proteolytic enzyme formed may depend on the composition of the medium.

Metalloproteases have been identified in both gram-positive and gram-negative pathogens so, they are certainly not unique to pathogenic species. There has been greater interest in the proteases of organisms which are pathogenic or of industrial importance than in those of organisms which lack either property (Claudia and Richard, 1993).

Present work aim to produce metalloprotease by $B$. thuringiensis 1257 strain which is considered to be a hyper producer, having the capability of utilizing agro industrial wastes(rice bran, wheat bran) as substrates followed by purification of the produced enzyme and measuring its activity and stability. 


\section{MATERIALS AND METHODS}

\section{Bacterial strains}

B. thuringiensis 1257(Eugeina and Yousten, 1975) was used in this study as metallo-protease-hyper-producing strains. In addition, thirty bacterial isolates previously isolated from KafrEl-Sheikh and Sadat City soil were tested for their ability to produce extracellular proteases.

\section{Media}

Peptone yeast extract (PY) medium (Bernhard et al, 1978) contained $10 \mathrm{~g}$ peptone, $5 \mathrm{~g}$ yeast extract, and $5 \mathrm{~g} \mathrm{NaCl}$ per liter. PA medium that is PY supplemented with $15 \mathrm{~g}$ agar per liter. The $\mathrm{pH}$ value was adjusted to be $\mathrm{pH} 7.0$ by $\mathrm{NaOH}$. PY and PA media were used to activate and to grow the Bacterial strains also PY media was used to grow bacterial strains to various times in order to monitor the protease activity. PA milk medium was PA supplemented with $7.5 \%$ skim milk. Physiological saline solution contained $8.5 \mathrm{~g} \mathrm{NaCl}$ per liter (Pleczar and Chan, 1977).

Basal medium (Saxena and Singh, 2011) contained $\left(0.1 \% \quad \mathrm{KH}_{2} \mathrm{PO}_{4}, 0.25 \%\right.$ $\mathrm{NaCl}, \quad 0.01 \% \mathrm{MgSO}_{4} .7 \mathrm{H}_{2} \mathrm{O}, \quad$ and $0.01 \% \mathrm{CaCl}_{2}$ ).

\section{Rapid screening for protease- hyper-producing bacteria}

The previous 30 bacterial isolates were tested for their ability to produce extracellular proteases on PA plates (Davis et al, 1980). All plates were incubated at $37^{\mathrm{O}} \mathrm{C}$ for $12-18$ hours. B. thuringiensis 1257 strain was also tested as a protease-hyperproducing strain. After the incubation period, the growth diameter of each bacterial colony was scored as $(\mathrm{y} \mathrm{cm})$ and the whole diameter (growth diameter including the clear zone) was scored as ( $\mathrm{x}$ $\mathrm{cm})$. The ratio (x/y) was taken as the base to choose the best protease-producing bacterial strains.

\section{activity}

Monitoring growth and proteolytic

B. thuringiensis 1257Cells were activated by growing them overnight on PA plates at $37^{\circ} \mathrm{C}$, then cells were allowed to grow for 24 hours at $30^{\circ} \mathrm{C}$. PY medium was inoculated with the above culture and was allowed to grow at $30^{\circ} \mathrm{C}$ with shaking. Growth was monitored by measuring the absorbance at $660 \mathrm{~nm}$ which was very much correlated with the number of viable cells. At the indicated time $5 \mathrm{ml}$ of the growing culture was taken and centrifuged at $6,000 \mathrm{rpm}$ for 10 minutes. The supernatants were used as a crude enzyme to measure the activity of the metalloprotease (Abdel-Aziz, 1993)

Monitoring growth and extracellular protease productionduring the utilization of wastes

B. thuringiensis 1257 cells were activated as described above. A hundred $\mathrm{ml}$ basal medium containing $5 \mathrm{gm}$ ofwaste was inoculated with the above culture. The new culture was allowed to grow at $30^{\circ} \mathrm{C}$ with shaking at $110 \mathrm{rpm}$ to the indicated time. At the indicated time one ml sample was taken and centrifuged at 8,000 rpm for 2 minutes. The supernatants were used as crude enzyme to measure the protease activity.

Spectrophotometric method of Protease activity

The activity of the protease was determined according to the method of Reichardet al. (1990) with some modifications. Reaction mixture $(2 \mathrm{ml})$ containing $10 \mathrm{mg}$ casein, $0.9 \mathrm{mM}$ Tris- $\mathrm{HCl}$ buffer, $\mathrm{pH} 7.2$, containing $100 \mu$ mole of $0.1 \mathrm{mM} \mathrm{CaCl}_{2}$ and $0.1 \mathrm{ml}$ (or an appropriate dilution) of samples. The reaction was carried out at $37^{\circ} \mathrm{C}$ for 30 minutes then it was terminated by the addition of $2 \mathrm{ml} \mathrm{5 \%}$ w/v trichloroacetic acid (TCA). Reactions were then kept on ice for 30 minutes after which they were centrifuged at $4000 \mathrm{rpm}$ for 10 minutes. The absorbance of the TCA soluble fractions were measured at $280 \mathrm{~nm}$. One unit of enzyme activity was equal to the amount of enzyme that liberates one micromole of tyrosine from casein per 30 minutes at $37^{\circ} \mathrm{C}$.

Electrochemical method of Protease activity 
Three separate DNNS-based protamine-sensitive membrane electrodes were used simultaneously to monitor the initial decrease in protamine levels (Chang et al, 1991). Experiments were performed by adding $5 \square$ of a $5 \mathrm{mg} / \mathrm{ml}$ protamine (Sigma, St. Louis, MO) solution to $1 \mathrm{ml}$ of Tris working buffer $(50 \mathrm{mM}$ Tris and 120 $\mathrm{mM} \mathrm{NaCl}, \mathrm{pH} 7.4$ ) to yield a final concentration of $25 \square \mathrm{g} / \mathrm{ml}$ protamine. After reaching a steady-state/ non-equilibrium response ( $3 \mathrm{~min}$ ), $100 \square 1$ of a preincubated (5 min) sample mixture containing MP was added to the solution. This preincubated sample mixture was composed of centrifuged bacterial culture solution in Tris working buffer. The decrease in the EMF response toward protamine was monitored over a 5-min period by each of the sensors. A calibration plot for MP was constructed by graphing the initial rate of the potential decrease, in $\mathrm{mV} / \mathrm{min}$ (average response of three sensors), vs MP activity, in IU/ml sample.

\section{Protein determination}

Determination of soluble proteins was carried out according to Bradford et al. (1976).

\section{Preparation of agro wastes}

The two environmental wastes (rice bran and wheat bran) were prepared for the bacterial utilization process. Basal medium II supplemented with $5 \mathrm{gms}$ of the waste was used to monitor the bacterial growth and the extracellular proteases produced by B. thuringiensis 1257.

\section{Purification of the extracellular} metalloprotease $\left(\mathrm{NH}_{4}\right)_{2} \mathrm{SO}_{4}$

Precipitation of metalloprotease by

The extracellular metalloprotease produced by $B$. thuringiensis 1257 was precipitated separately by ammonium sulfate ( $70 \%$ saturation) in an ice-bath then it was allowed to stand for 1 hour at $4^{\mathrm{O}} \mathrm{C}$. The above mixture was centrifuged at 6,000 rpm for 30 minutes. Pellets were dissolved in a minimal volume of $0.1 \mathrm{M}$ Tris- $\mathrm{HCl}$ buffer, $\mathrm{pH} 7.2$ then dialyzed overnight against the same buffer. The protein content and the metalloprotease activity for the dialyzed enzyme samples were determined as above.

Purification of metalloprotease by Sephadex G-75 column

Two $\mathrm{ml}$ of the dialyzed metalloprotease was applied to the Sephadex G-75 $(1.5 \times 20 \mathrm{~cm})$ column with the aid of an adaptor. The enzyme was eluted with $0.1 \mathrm{M}$ Tris- $\mathrm{HCl}, \mathrm{pH} \quad 7.5$ containing $10 \mathrm{mM} \mathrm{CaCl} 2$ at a flow rate of $36 \mathrm{ml} /$ hours. Fractions $(3 \mathrm{ml})$ were collected at $4^{\mathrm{O}} \mathrm{C}$ after which the absorbance at $280 \mathrm{~nm}$ and the enzyme activity were determined. The active fractions were tested separately against certain inhibitors, EDTA which is considered to be specific inhibitor of metalloprotease (Dancerand Mandelstam 1975; Aderibigbe andOdunfa 1988; Rufoet al, 1990). Active fractions were collected and reprecipitated on ice with solid $\left(\mathrm{NH}_{4}\right)_{2} \mathrm{SO}_{4}$. After standing overnight at $4^{\mathrm{O}} \mathrm{C}$, the precipitate was removed by centrifugation at $6,000 \mathrm{rpm}$ for 30 minutes at $4{ }^{\mathrm{O}} \mathrm{C}$. The precipitate was redis solved in a small volume of the above buffer and stored at $-20^{\circ} \mathrm{C}$ to be used in the characterization experiments. metalloprotease

Characterization of the purified Determination of optimum $\mathbf{p H}$

The optimum $\mathrm{pH}$ of the purified extracellular metalloprotease was determined over a $\mathrm{pH}$ range (4-12). The buffers used in this test were $0.1 \mathrm{M}$ acetate buffer for $\mathrm{pH} 4$ and $\mathrm{pH} 6,0.1 \mathrm{M}$ Tris-HCl buffer for $\mathrm{pH} 7.0$ and $\mathrm{pH} 8.0$, and $0.1 \mathrm{M}$ carbonate buffer for $\mathrm{pH} 9.0,10.0,11.0$ and $\mathrm{pH}$ 12.0. The reaction mixture $(2 \mathrm{ml})$ contained buffer (at the desired $\mathrm{pH}$ ), $10 \mathrm{mg}$ casein powder and $10 \square 1$ purified enzyme was allowed to stand at $37^{\circ} \mathrm{C}$ with shaking for 30 minutes. The reaction mixture was stopped by the addition of TCA then it was filtered and the activity of the enzyme was determined as described before.

\section{Effect of inhibitors}

To study the effect of protease inhibitors on the proteolytic activity, 
different concentrations (1-15 $\mathrm{mM})$ of EDTA were used by adding the corresponding inhibitors to the reaction mixture, incubated at $37{ }^{\circ} \mathrm{C}$ for $1 \mathrm{~h}$. without the substrate fraction and assayed as described above.

\section{RESULTS AND DISCUSSION \\ Screening for protease-hyper- producing bacteria}

In an attempt to produce extracellular metalloproteases by microorganisms through the process of waste biodegradation screening was carried out to choose suitable strains for the commercial production of bacterial extracellular proteases. Bacteria often produce enzymes in large quantities when they grow on suitable media. In the search for metalloprotease hyper-producing strains, thirty bacterial isolates (isolated from different soil samples in KafrElshaikh and Menofiya governerares) were screened on PA milk plates. A part of the present study was focused on screening the above isolates using tooth-picking (Daviset al,
1980). Single colonies were transferred using toothpicks (pre-sterilized wood toothpicks) to PA Milk plate in order to check the ability of the isolates to produce extracellular proteases. The ratio of the whole diameter (diameter of the clear zone including colony size, $\mathrm{x}$ ) over that of bacterial growth (y) was taken as an indicator for the production of extracellular proteases. Results of this work are presented in Table 1. Twelve isolates showed relatively high $(\mathrm{x} / \mathrm{y})$ values. The table contains results of the screened isolates compared with $B$. thuringiensis which was taken as a metalloproteasehyperproducing strain. Data indicated that $B$. thuringiensis was the most extracellular protease producing strain. Results obtained from comparing extracellular enzyme production percentage showed that $B$. thuringiensis was almost three times greater than other isolates. Extracellular enzyme production of the reference strain is shown in Figure (1)

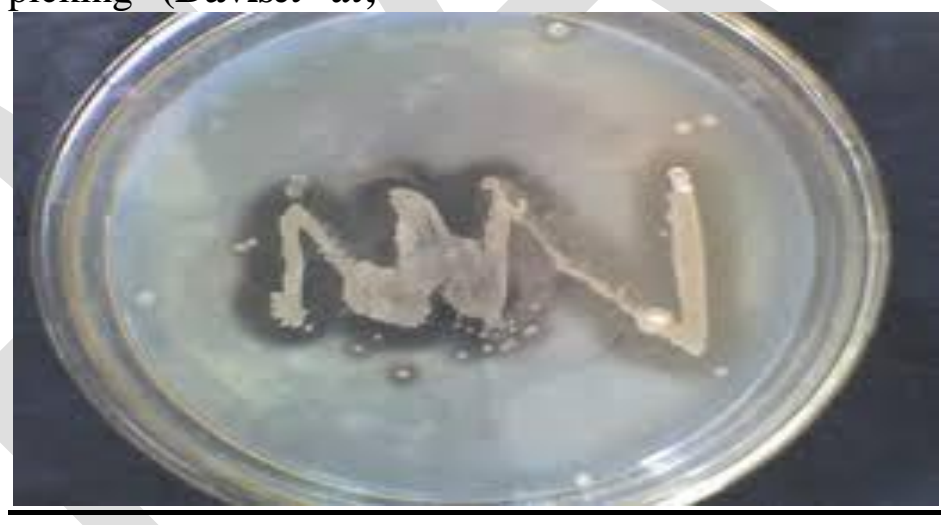

Figure (1): Extracellular proteases production of B.thuringiensis. Picture was taken after incubating freshly prepared strain on PY milk plate at $37^{\circ} \mathrm{C}$ for 12 hours. 
Table 1. Screening of different bacterial isolates for their extracellular proteases production.

\begin{tabular}{||c|c|c|c||c||}
\hline $\begin{array}{c}\text { Bacterial } \\
\text { isolate }\end{array}$ & $\begin{array}{c}\text { Growth } \\
\text { diameter } \\
\text { (Y cm) }\end{array}$ & $\begin{array}{c}\text { Whole } \\
\text { diameter } \\
\text { (X cm) }\end{array}$ & $(\mathbf{X} / \mathbf{Y})$ & $\begin{array}{c}\text { Production } \\
\text { \%* compared } \\
\text { with ref. } \\
\text { strain }\end{array}$ \\
\hline EI001 & 1.4 & 1.5 & 1.07 & 31.2 \\
EI002 & 1.6 & 1.8 & 1.13 & 32.8 \\
EI003 & 1.2 & 1.5 & 1.25 & 36.4 \\
EI004 & 1.5 & 1.7 & 1.13 & 33.0 \\
EI005 & 1.3 & 1.6 & 1.23 & 35.9 \\
EI006 & 1 & 1.1 & 1.10 & 32.1 \\
EI007 & 1.7 & 1.9 & 1.12 & 32.1 \\
EI008 & 1.8 & 1.9 & 1.06 & 32.6 \\
EI009 & 1.8 & 1.9 & 1.06 & 30.8 \\
EI010 & 1.5 & 1.7 & 1.13 & 30.8 \\
EI011 & 1.7 & 2.1 & 1.24 & 36.0 \\
EI012 & 1.4 & 1.7 & 1.21 & 35.4 \\
B. thuringiensis & 0.7 & 2.4 & 3.43 & 100.0 \\
\hline
\end{tabular}

$* \%=$ The ability of the bacterial isolates to produce proteolytic activity compared to $B$. thuringiensis.

Monitoring enzyme activity during microbial growth curve

To optimize the whole process of biodegradation, production of extracellular proteases produced by B.thuringiensis was carried out on the synthetic medium PY at different temperatures. PY was chosen as a protein rich medium to enhance enzyme production. Best results of enzyme production are shown in figures (2) and (3). Production starts early in the exponential phase, to help the microbe in performing all its anabolic processes. Production reached more than $2000 \mathrm{U} / \mathrm{ml}$ after three hours of incubation at $30^{\circ} \mathrm{C}$ (Fig. 2)

Similar results were obtained after incubating the microbe at $37^{\circ} \mathrm{C}$ on the same medium (Fig. 3). Enzyme activity reached more than $1200 \mathrm{U} / \mathrm{ml}$ after three hours of incubation.

All the process of enzyme production was carried out as mentioned above using the two environmental wastes (rice bran and wheat bran) as mentioned in materials and methods. Wheat bran give more than $600 \mathrm{U} / \mathrm{ml}$ after incubation in the same conditions (results not shown)

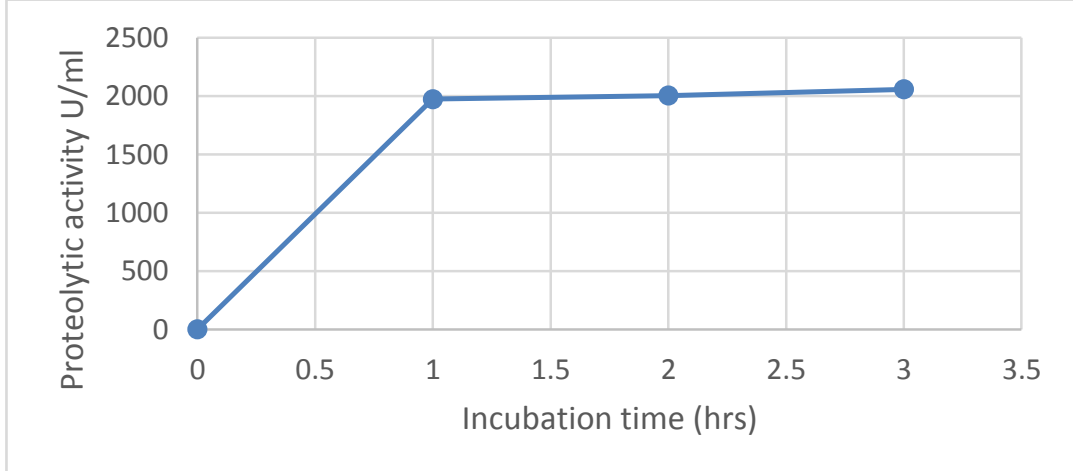



at $30^{\circ} \mathrm{C}$

Figure (2): Proteolytic activity of B.thuringiensis after incubation on PY medium

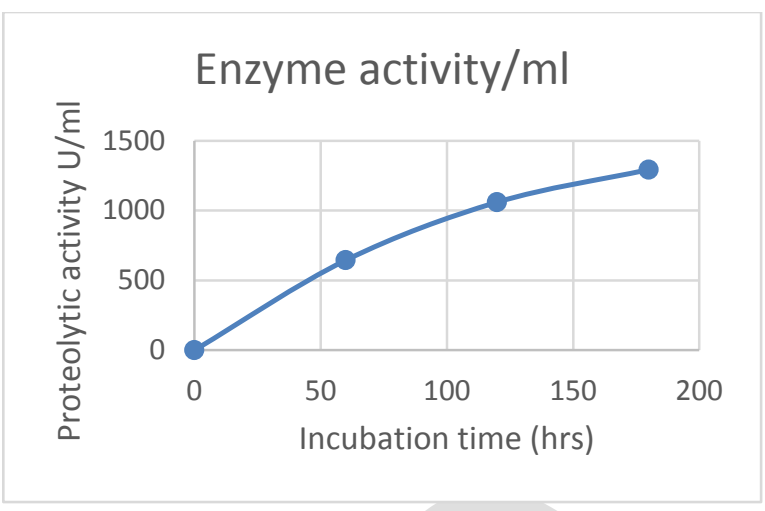
at $37^{\circ} \mathrm{C}$

Figure (3): Proteolytic activity of B.thuringiensis after incubation on PY medium

\section{Identification of extracellular protease}

To identify extracellular protease produced by B.thuringiensis partially purified enzyme was prepared by $70 \%$ ammonium sulfate precipitation. Enzyme activity was carried out according to the method of Reichardet al. (1990) with some modifications. Reaction mixture contained powder casein as the enzyme substrate. Reaction mixture was Tris- $\mathrm{HCl}$ buffer, $\mathrm{pH}$ 7.2 that contained $\mathrm{CaCl}_{2}$. Previous mixture was taken as the control sample for all protease activity. EDTA was added to the reaction mixture in a split sample to compare proteolytic activity.
Table 2 shows activity of partially purified extracellular protease produced by B.thuringiensis. The table also shows comparison of proteolytic activity after assaying with and without the chelating EDTA compound. Residual activity of the enzyme was dropped to almost one third of its original value after addition of $1 \mathrm{mM}$ EDTA to the reaction mixture. Moreover, the enzyme lost more than $75 \%$ of its original proteolytic activity at $10 \mathrm{mM}$ EDTA concentration.

Previous results categorize the extracellular protease produced by the microbe as a metalloprotease.

Table (2): Identification ofextracellular protease produced by B.thuringiensis

\begin{tabular}{|c|c|c|}
\hline mM EDTA added & $\begin{array}{c}\text { Enzyme activity } \\
(\mathbf{U} / \mathbf{m l}) *\end{array}$ & $\begin{array}{c}\text { Residual activity } \\
\text { \% }\end{array}$ \\
\hline 0 & 1176 & 100.0 \\
\hline 1 & 430 & 36.6 \\
\hline 5 & 310 & 26.4 \\
\hline 10 & 270 & 23.0 \\
\hline 15 & 236 & 20.1 \\
\hline
\end{tabular}

* One unit of enzyme activity was equal to the amount of enzyme that liberates one micromole of tyrosine from casein per 30 minutes at $37^{\circ} \mathrm{C}$. 
Electrochemical enzyme detection

Detection with polycation-sensitive electrodes

Assaying metalloprotease with electrochemical detectors, such as polymer membrane-based ion-selective electrodes offers a number of advantages over spectrophotometric methods especially in cases where samples are highly colored or turbid like bacterial cultures.

Protamine-sensitive membrane electrodes have been used to measure trypsin activity (Yun et al, 1995). Protamine is an arginine-rich protein which is known to be an excellent substrate to proteases (Ong and Johnson, 1976). Polyion-sensitive electrodes have a high response towards protamine (Chang et al. 1996).
Metalloprotease activity was detected by measuring the initial rate of decrease in the potentiometric response of the polycation-sensitive membrane electrode towards protamine degradation by the action of enzyme. Figure (4) show the average potentiometric responses of tubular dinonylnaphthalene sulfonate (DNNS)based protamine-sensitive membrane electrodes toward $25 \square \mathrm{g} / \mathrm{ml}$ protamine and the effect of adding increased concentrations of metalloprotease. All measurements were compared to split samples that were measured with spectrophotometric casein hydrolysis method. Both electrochemical and spectrophotometric enzymatic detection offered a robust and reliable method that can be used to assay for metalloprotease produced by B.thuringiensis.

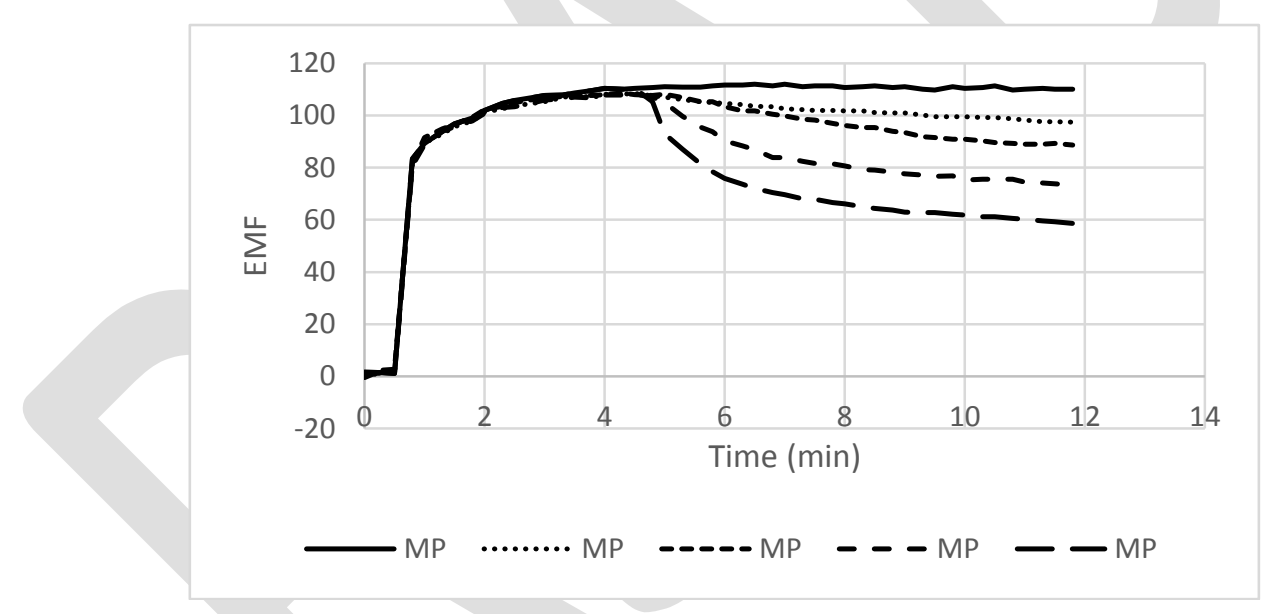

Figure (4).Potentiometric response of (DNNS)-based protamine-sensitive membrane electrodes towards $25 \square \mathrm{g} / \mathrm{ml}$ protamine and subsequent addition of $100 \square \mathrm{lof}$ standard metalloprotease.

\section{Optimum pH for enzyme activity}

Results of optimum $\mathrm{pH}$ and stability range of extracellular metalloprotease produced by $B$. thuringiensis at different buffer systems are shown in table (3) and figure (5). The enzyme retained more than $50 \%$ of its activity over the $\mathrm{pH}$ range (6-9) with an optimum $\mathrm{pH}$ of 8 . A very little decrease in the residual activity (less than 5 percent) was shown at $\mathrm{pH} 7$.

To test for the effect of different storage buffers on the residual activity of extracellular metalloprotease produced by $B$. thuringiensis, the enzyme was preincubated for one hour in different buffer systems $(0.1 \mathrm{M}$ acetate buffer for $\mathrm{pH} 4-6$, $0.1 \mathrm{M}$ Tris- $\mathrm{HCl}$ buffer for $\mathrm{pH} 7.0$ and $\mathrm{pH}$ 8.0, and $0.1 \mathrm{M}$ carbonate buffer for $\mathrm{pH} 9.0$, and $\mathrm{pH} 10.0$ ). Figure (6) showed that the residual of the pre-incubated enzyme was almost not affected over the alkaline $\mathrm{pH}$ range (8-11). On the other hand, activity was greatly decreased upon incubating the enzyme in acidic $\mathrm{pH}$ buffers. 
Table (3): Optimum pH for activity of extracellular metalloprotease produced by B. thuringiensis

\begin{tabular}{|c|c|c|}
\hline $\mathbf{p H}$ & Enzyme activity U/ml & Residual activity \% \\
\hline 4 & 151 & 18.9 \\
\hline 5 & 250 & 31.2 \\
\hline 6 & 404 & 50.4 \\
\hline 7 & 764 & 95.4 \\
\hline 8 & 801 & 100.0 \\
\hline 9 & 414 & 51.7 \\
\hline 10 & 391 & 48.8 \\
\hline
\end{tabular}

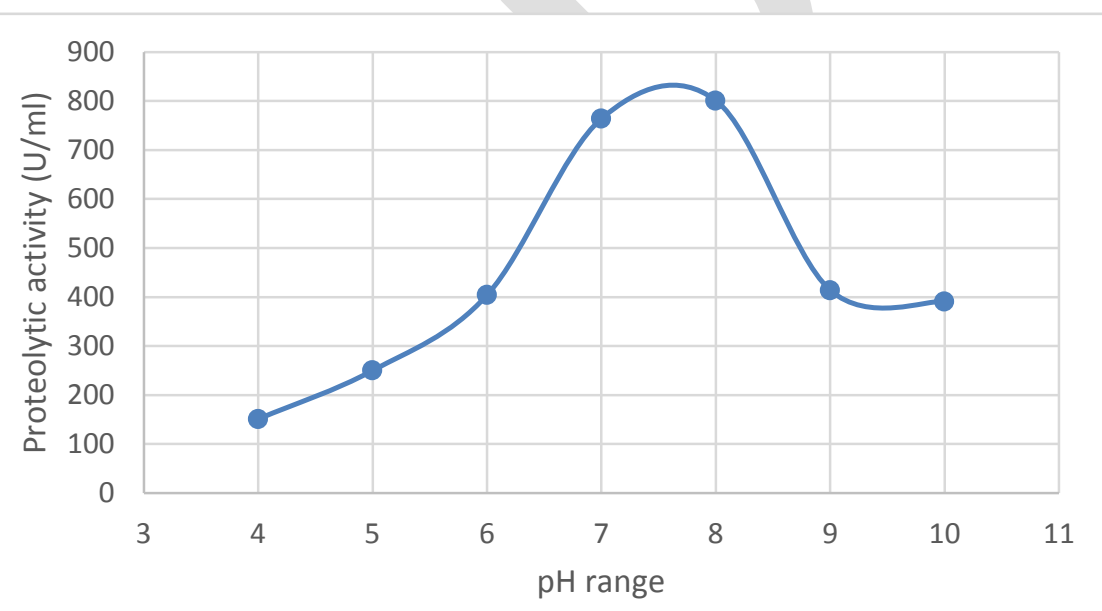

Figure (5): Effect of pH on the activity of extracellular metalloprotease produced by $B$. thuringiensis. Enzyme activity was carried out as mentioned in materials and methods.

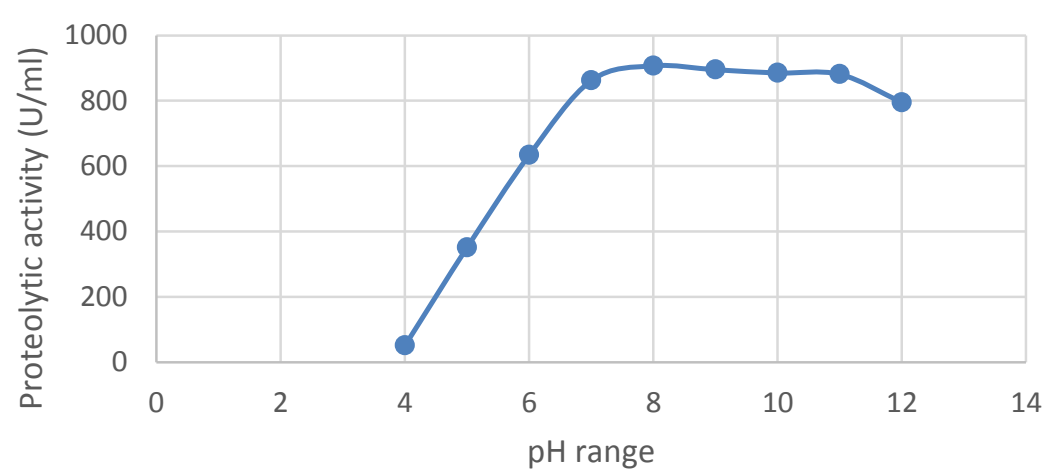

Figure (6): Effect of pH stability range on the activity of extracellular metalloprotease produced by $B$. thuringiensis. Enzyme activity was carried out with the buffer systems $(0.1 \mathrm{M}$ acetate buffer for $\mathrm{pH} 4-6,0.1 \mathrm{M}$ Tris-HCl buffer for $\mathrm{pH} 7.0$ and pH 8.0, and 0.1 $M$ carbonate buffer for $\mathrm{pH} 9.0$, and $\mathrm{pH} 10.0$ )

Purification of extracellular metalloprotease produced by $B$. thuringiensis
B.thuringiensis cells were grown on PY medium until the proteolytic activity reached its maximum. The culture was 
chilled in an ice bath and cells were removed by centrifugation. The crude enzyme solution was precipitated with ammonium sulfate ( $70 \%$ saturation) and dialyzed against Tris- $\mathrm{HCl}$ buffer as mentioned in Materials and Methods. This step resulted in more than 29-fold purification of the enzyme (Table 4). Dialyzed enzyme was applied to a
Sephadex G-75 column at a flow rate of 36 $\mathrm{ml} / \mathrm{hr}$. The total proteolytic activity of the enzyme eluted also appeared in a single peak that overlapped with the protein peak. This would indicate that most proteins are actually in the form of proteases. The gel filtration step resulted in more than 60 -fold purification.

Table (4): Purification table of metalloprotease produced by B.thuringiensis cells

\begin{tabular}{|l|l|l|l|l|l|l|}
\hline Purification step & $\begin{array}{l}\text { Mg } \\
\text { protein/ml }\end{array}$ & $\begin{array}{l}\text { Metallo } \\
\text { protease } \\
\text { Units/ml }\end{array}$ & $\begin{array}{l}\text { Total } \\
\text { volume } \\
(\mathbf{m l})\end{array}$ & $\begin{array}{l}\text { Total } \\
\text { units }\end{array}$ & $\begin{array}{l}\text { Specific } \\
\text { activity }\end{array}$ & $\begin{array}{l}\text { Fold } \\
\text { purification }\end{array}$ \\
\hline $\begin{array}{l}\text { Cell free supernatant } \\
\text { Pellets after }\left(\mathrm{NH}_{4}\right)_{2} \mathrm{SO}_{4} \\
\text { ppt. }\end{array}$ & 3.3 & 25.0 & 82.0 & 2050.0 & 7.6 & 1.0 \\
$\begin{array}{l}\text { Pellets after dialysis } \\
\text { Gel filtration }\end{array}$ & 2.2 & 853.0 & 2.0 & 1706.0 & 222.1 & 29.3 \\
\hline
\end{tabular}

\section{CONCLUSION}

Thirty bacterial isolates, previously isolated from the soil of KafrElshaikh and Menofiyagovernerates, were examined for their ability to hydrolyze milk and consequently their ability to synthesis and to secrete extracellular proteases. These isolates were screened and tested together with Bacillus thuringiensis as a hyper producer of metalloprotease. The production of the extracellular metalloprotease by this strain was about 3 to 4-fold higher than that of other isolates.

The extracellular metalloprotease produced by Bacillus thuringiensis cells was purified next. The enzyme was purified through $\left(\mathrm{NH}_{4}\right)_{2} \mathrm{SO}_{4}$ precipitation followed by a gel filtration Sephadex G-75 column. Data illustrate that the enzyme was purified to almost 29-fold just by the selective precipitation $\quad\left(70 \% \quad\left(\mathrm{NH}_{4}\right)_{2} \mathrm{SO}_{4}\right.$ precipitation) with a recovery of about $83 \%$ of total units. Further purification using the Sephadex G-75 column resulted in increasing the fold purification to about 60fold with $55 \%$ recovery of total units. The proteolytic activity was shown to be almost totally inhibited by EDTA and this would indicate that most the purified enzyme (if not all) is actually metalloprotease.

The optimum $\mathrm{pH}$ of the purified metalloprotease was about $\mathrm{pH} 8$ with a stability range in the alkaline $\mathrm{pH}$.

The study also pointed at the possibility of using the microbe to direct the microbial utilization of two environmental protein-rich wastes. Rice bran and wheat bran, in basal medium, were utilized by the above bacterial cells and thus, a considerable amount of metalloprotease was produced. Produced enzyme was also detected using both spectrophotometric and electrochemical detection methods and both were found to be reliable in enzymatic assay.

\section{REFERENCES}

Abdel-Aziz, A.S. (1993). Bacterial proteases and some of their uses in biotechnology. Master thesis, Department of Bioscience and Technology, Institute of Graduate Studies and Research, University of Alexandria.

Aderibigbe, E.Y. and S.A. Odunfa (1988). Purification and characterization of extracellular proteinases excreted by a strain of Bacillus subtilis BS2 isolated from 
fermented African locust bean 'iru'. J. Appl. Bacteriol. 65:361-369.

Baker, A. H., D. R. Edwards and G. Murphy (2002). Metalloproteinase inhibitors: biological actions and therapeutic opportunities. Journal of Cell Science.115: 3719-3727.

Bernhard, K., H. Schrempf, and W. Goebel (1978). Bacteriocin and antibiotic resistance plasmids in Bacillus cereus and Bacillus subtilis. J. Bacteriol. 133:897-903.

Bradford, M.M. (1976). A rapid and sensitive method for the quantitation of microgram quantities of protein utilizing the principle of protein-dye binding. Anal. Biochem. 72: 248-254.

Chang, L.C., M.E. Meyerhoff and V.C. Yang (1991). Electrochemical assay of plasminogen activators in plasma using polyion-sensitive membrane electrode detection. Anal. Biochem. 276:8-12.

Chang, L.C., M.E. Meyerhoff, and V.C. Yang, (1999). Electrochemical assay of plasminogen activators in plasma using polyion-sensitive membrane electrode detection. Anal. Biochem. 276: 8-12

Claudia, C. H. and Richard, A. F. (1993). Bacterial extracellular zinccontaining metalloproteases. Microbiological Reviews. 57: 823-837.

Dancer, B.N., and J. Mandelstam (1975). Production and possible function of serine protease during sporulation of Bacillus subtilis. J. Bacteriol. 121:406-410.

Davis, R.W., D. Botstein, and J.R. Roth (1980). Advanced bacterial genetics: A manual for genetic engineering. Cold Spring Harbor Laboratory, Cold Spring Harbor, New York 11724 USA.

Eugeina, Li. and A. A. Yousten (1975). Metalloprotease from Bacillus thuringiensis. Applied Microiology. 30:354-361.

Gaustevora, A., D. Braikova, P. Christov, K. Tishinov, E. V. Tonkova, T.Haertle and P. Nedkov (2005). Degradation of keratin and collagen containing wastes by newly isolated. Thermnoactivomycetes or by alkaline hydrolysis .Lett. Appl. Microbiol. . 40: 335340.

Holmquist, B. and Vallee, B.L. (1974). Metal substitutions and inhibition of thermolysin: spectra of the cobalt enzyme. J. Biol. Chem. 249: 4601-4607.

Hooper, N.M. (1994). Families of zinc metalloproteases. FEBS Lett. 354: 1-6.

Khokha, R., A. Murthy and A. Weiss (2013). Metalloproteinases and their natural inhibitors in inflammation and immunity. Nature Reviews Immunology. 13:649-665.

Murphy, G. and M. H. Lee (2005). The roles of metalloproteinases in cartilage and bone damage. Ann Rheum Dis.64: iv44-iv47.

Nagase, H. (2001). Current Protocols in Protein Science., Metalloproteases, Chapter 21, Unit 21.4, John Wiley and Sons, Inc.

Ong, E.B., and A.J. Johnson, (1976). Protamine, a substrate for thrombolytic agents and enzymes of similar specificity. Anal. Biochem. 75: 568-582

Pleczar, M.J., and E.C. Chan (1977). Laboratory exercises in microbiology, 4th edition, M.J. Pleczar and E.C. Chan (ed.). McGraw-Hill, Inc.

Reichard, U., S.Buttner, H.Eiffert, F.Staib and R.Ruchel (1990). Purification and characterization of an extracellular serine proteinase

from Aspergillus fumigatus and its detection in tissue. J. Med. Microbiol. 33: 243-251.

Rufo, G.A., B.J. Sullivan, A. Sloma, and J. Pero (1990). Isolation and characterization of a novel extracellular metalloprotease from Bacillus subtilis. J. Bacteriol. 172:1019-1023.

Saxena, R. and Singh, R. (2010). Metal ion and $\mathrm{pH}$ stable protease production using Agro- industrial waste. J Ecobiotechnol 2:01-05.

Saxena, R. and Singh, R. (2011). Characterization of a metallo-protease produced in solid state fermentation by a newly isolated Bacillus strain.Acta Biol Szeged. 55:13-18. 
Vallee, B.L.; Auld, D.S.(1990). Zinc coordination, function, and structure of zinc enzymes and other proteins. Biochemistry. 29: 5647-5659.
Yun, J.H., M.E. Meyerhoff, and V.C. Yang, (1995). Protamine-sensitive polymer membrane electrode: characterization and bioanalytical applications. Anal. Biochem. 224: $212-220$ 